\title{
Review Manajemen Rantai Pasok Produk Pertanian Berkelanjutan: Konseptual, Isu Terkini, dan Penelitian Mendatang
}

\section{(A Review of Sustainable Agric-Supply Chain Management: Conceptual, Current Issue, and Future Research)}

\author{
Rachman Jaya $^{1^{*}}$, Yusriana ${ }^{2}$, Eka Fitria ${ }^{1}$ \\ (Diterima Mei 2020/Disetujui November 2020)
}

\begin{abstract}
ABSTRAK
Pada saat ini, topik penelitian mengarah ke manajemen rantai pasok berkelanjutan pada sektor pertanian. Hal ini dapat dilihat dari peningkatan artikel dengan topik tersebut. Manajemen rantai pasok berkelanjutan merupakan pengembangan dari manajemen rantai pasok konvensional yang mengintegrasikan aspek ekonomi, sosial, dan lingkungan dalam pencapaian tujuan organisasi. Tujuan kajian ini adalah memetakan kondisi kekinian dan menentukan topik utama penelitian pada masa mendatang. Artikel diunduh dari beberapa laman penyedia artikel ilmiah, seperti Science Direct, Ebsco, Cross-reff, Researchgate, Academia.edu, DOAJ, dan Google Scholar. Jumlah artikel yang dikaji adalah 112 naskah, dengan tahun terbit berkisar tahun 2003-2020. Spesifikasi kajian ditentukan berdasarkan review literatur sistematik. Klasterisasi dilakukan berdasarkan topik kajian, yaitu manajemen rantai pasok, manajemen rantai pasok berkelanjutan, dan manajemen rantai pasok berkelanjutan produk pertanian. Analisis konten dilakukan untuk melihat kondisi kekinian dan kebaharuan substansi yang dikaji. Hasil kajian menunjukkan bahwa sangat penting bagi pelaku bisnis pertanian untuk mengimplementasikan konsep berkelanjutan (dimensi ekonomi, sosial, lingkungan, dan kelembagaan) pada sistem rantai pasok produk pertanian dengan pendekatan industri 4.0 agar proses bisnis dapat terjamin. Pada bagian akhir dilakukan sintesis dan topik-topik utama penelitian pada masa mendatang.
\end{abstract}

Kata kunci: manajemen, produk pertanian, rantai pasok berkelanjutan

\section{ABSTRACT}

Recently, the interest of academic and research institutions in sustainable agric-supply chain management (SASCM) has risen. This fact can be seen from the number of papers published as special issues. Agric-supply chain management is a substance deepening from conventional supply chain management which is discussing integration of economical, environmental, and social aspects to reach a goal of organization. The objective of this research was to describe the state of the art about this topic and future research issues. The number of papers analyzed were 111 articles published from 2003-2020. The articles were obtained from scientific provider such as Science direct, EBSCO, Cross-Reff, Researchgate, DOAJ, Academia.Edu, and Google Scholar. In this research, we cluster (SASCM) to several items such as supply chain management, sustainable supply chain management, and sustainable supply chain management for agricultural product. The content analysis was used to describe the state of the arts and novelty. The result of the study show that it is critical for the actors of agricultural business to apply sustainability concepts including economic, social, environmental, and institution on the systems of agricultural supply chain based on industry 4.0 approach to reach a sustainable business process. Synthesis and determination of main topics of research in the future is undertaken at the end.

Keywords: agricultural product, management, sustainable supply chain

\section{PENDAHULUAN}

Pada awalnya, manajemen rantai pasok hanya fokus pada sistem logistik (Liu et al. 2017) dan mulai digunakan pada tahun 1982. Secara konvensional, Lu (2011) menyatakan bahwa manajemen rantai pasok adalah jaringan (network) perusahaan-perusahaan (independen/grup) yang secara bersama-sama

${ }^{1}$ Balai Pengkajian Teknologi Pertanian Aceh, JL. Panglima Nyak Makam, No. 27, Lampineung, Banda Aceh 23125

2 Program Studi Teknologi Hasil Pertanian, Fakultas Pertanian Universitas Syiah Kuala, Jl. Teuku Nyak Arief No.441, Aceh 23111

*Penulis Korespondensi: Email: jaya.rachman@yahoo.co.id bekerja menciptakan dan menghantarkan suatu produk ke pengguna akhir (farm to the table). Dalam prosesnya, manajemen rantai pasok menyangkut aliran barang, informasi, dan uang (Vorst 2004; Gumus \& Guneri 2009). Selain itu, manajemen rantai pasok juga menyangkut proses desain perencanaan, produksi, inventori, transportasi, dan retail suatu produk dan jasa, termasuk juga pengelolaan limbah (Thomas \& Griffin 1996; Christoper 1998; Beamon 1998; Fritz 2019). Pada saat ini, era manajemen rantai pasok masuk ke sistem berbasis teknologi informasi untuk meningkatkan kreativitas (value creation), sharing informasi dan kolaborasi masing-masing aktor yang terlibat. Dalam hal ini, pertanyaan yang muncul 
adalah bagaimana nilai (value) tersebut dibangun dan bagaimana pula mendistribusikannya ke setiap aktor yang terlibat (Boiko et al. 2019).

Pada sisi yang lain, sistem manajemen rantai pasok (demand) juga dituntut tidak hanya membahas aspek ekonomi, akan tetapi juga aspek lingkungan dan sosial untuk mencapai tujuan perusahaan (Cuthberson 2011; Vural 2015; Saeed \& Kersten 2019), bahkan aspek kelembagaan. Hal inilah yang menjadi dasar rantai pasok berkelanjutan (Al-odeh \& Smallwood 2012). Kerangka dasar manajemen rantai pasok berkelanjutan (MRPB) adalah konsep pembangunan berkelanjutan (Adam \& Ghaly 2007; Vermeulen \& Kok 2012; Klarin 2018). Manajemen rantai pasok berkelanjutan merupakan pengembangan manajemen rantai pasok konvensional, yang di dalamnya terdapat interrelasi aspek ekonomi, sosial, dan lingkungan, dengan tujuan agar rantai pasok yang dikelola dapat memenuhi keinginan konsumen (responsiveness) dalam hal kualitas, kuantitas, time delivery, berwawasan lingkungan, dan peka terhadap kondisi sosial kemasyarakatan (Seuring \& Muller 2008; Ageron et al. 2011; Seuring, 2012; Golisic \& Smith 2013; Tebaldi et al. 2018). Fokus topik ini adalah bagaimana perusahaan-perusahaan mampu beradaptasi terhadap kompleksitas komponen-komponen tersebut dalam menjalankan sistem produksi secara berkelanjutan (Gunasekaran et al. 2014).

Berdasarkan kerangka logis artikel ilmiah (scientific based) muncul pertanyaan seperti apa hubungan antara manajemen rantai pasok dan manajemen rantai pasok berkelanjutan, yang menjadi point dalam naskah ini. Secara harfiah, manajemen rantai pasok adalah proses kolaborasi aktor yang terlibat dalam merancang, memproduksi, mengantarkan (delivery), dan menjual (retail) suatu produk sampai ke konsumen akhir. Sementara itu, manajemen rantai pasok berkelanjutan adalah proses kolaborasi tersebut harus memperhatikan tidak hanya aspek ekonomi, tetapi juga aspek lingkungan dan sosial, bahkan kelembagaan. Hal inilah yang akan diungkapkan pada artikel ini, melalui telaah literatur. Sebagai ilustrasi disampaikan substansi kajian pada sektor pertanian yang menjadi tulang punggung penyediaan pangan, baik lingkup lokal, regional, maupun nasional.

Tujuan penelitian ini adalah memberikan gambaran sejauh mana (state of the art) kegiatan penelitian dan isu-isu utama (future research) topik manajemen rantai pasok produk pertanian berkelanjutan telah dilaksanakan. Sistematika penelitian yang menyangkut pokok bahasan mengenai transformasi sistem manajemen rantai pasok, kemudian spesifik manajemen dan dinamika aspek konseptual (ekonomi, sosial, lingkungan, dan kelembagaan) rantai pasok produk pertanian berkelanjutan, termasuk juga basis komoditas yang diteliti serta model yang digunakan. Pada artikel ini, disampaikan juga ilustrasi mengenai manajemen rantai pasok berkelanjutan pada komoditas pertanian. Pada bagian akhir dibahas topik isu-isu penting yang dapat dijadikan rujukan bagi peneliti untuk melaksanakan penelitian pada masa mendatang. Keterbatasan artikel ini adalah telaah literatur yang dilakukan belum mencakup aspek metode/model yang digunakan, demikian juga dengan peran pemerintah dalam mengelola sistem rantai pasok produk pertanian berkelanjutan.

\section{METODE PENELITIAN}

Kajian ini dilakuan berdasarkan telaah literatur yang berhubungan dengan topik kajian, yaitu rantai pasok berkelanjutan pada sektor pertanian, dengan mengaplikasikan konsep telaah pustaka sistematik. Artikel-artikel yang digunakan sebagian besar diunduh dari beberapa situs (website) penyedia artikel ilmiah, antara lain: Elsevier, Science Directs, Ebsco, Researchgate, Academia.edu, Google Scholar, Crossreef, dan DOAJ. Kata kunci yang digunakan antara lain: sustainable, sustainability, supply chain, supply chain management, green supply chain, agricultural product atau kombinasi di antaranya.

Artikel yang dianalisis mencapai 112 artikel (Gambar 1), dengan tahun terbit dari tahun 2003-2020 (Gambar 2). Dalam hal ini dapat dikatakan bahwa rentang waktu publikasi sesuai dengan perkembangan dan transformasi substansi kajian (state of the art). Artikel yang sudah diunduh diklaster ke beberapa kelompok (folder), yaitu menyangkut dasar manajemen rantai pasok, manajemen rantai pasok berkelanjutan, dan manajemen rantai pasok berkelanjutan produk pertanian. Terhadap materi kajian dilakukan analisis konten (Hsieh \& Shannon 2005). Tahapan-tahapan merupakan analisis konten, yang dideskripsikan pada Gambar 3.

Berdasarkan Gambar 3 terlihat bahwa proses kajian mengacu pada konsep review literatur sistematik. Secara detail, analisis dilakukan terstruktur berupa klasterisasi substansi kajian, yaitu manajemen ratai pasok, manajemen rantai pasok berkelanjutan, dan manajemen rantai pasok berkelanjutan pada produksi pertanian. Analisis konten dilakukan untuk mengkaji temuan yang diungkapkan artikel dan sintesis pada artikel yang memiliki kaitan erat, demikian juga dengan teknik yang digunakan.

\section{HASIL DAN PEMBAHASAN}

\section{Manajemen Rantai Pasok}

Rantai pasok (RP) merupakan integrasi proses dari beberapa entitas bisnis (grup/mandiri) yang mencakup pengadaan bahan baku, proses pengolahan menjadi bahan jadi/setengah jadi, dan mengantarkannya ke pengguna akhir (Beamon 1998; Chopra 2003) termasuk juga produk-produk pertanian (Apaiah \& Hendrix 2004; Ahumda \& Valalobos 2009). Pada awalnya, istilah manajamen rantai pasok (MRP) digunakan oleh konsultan pada awal tahun 80-an, 


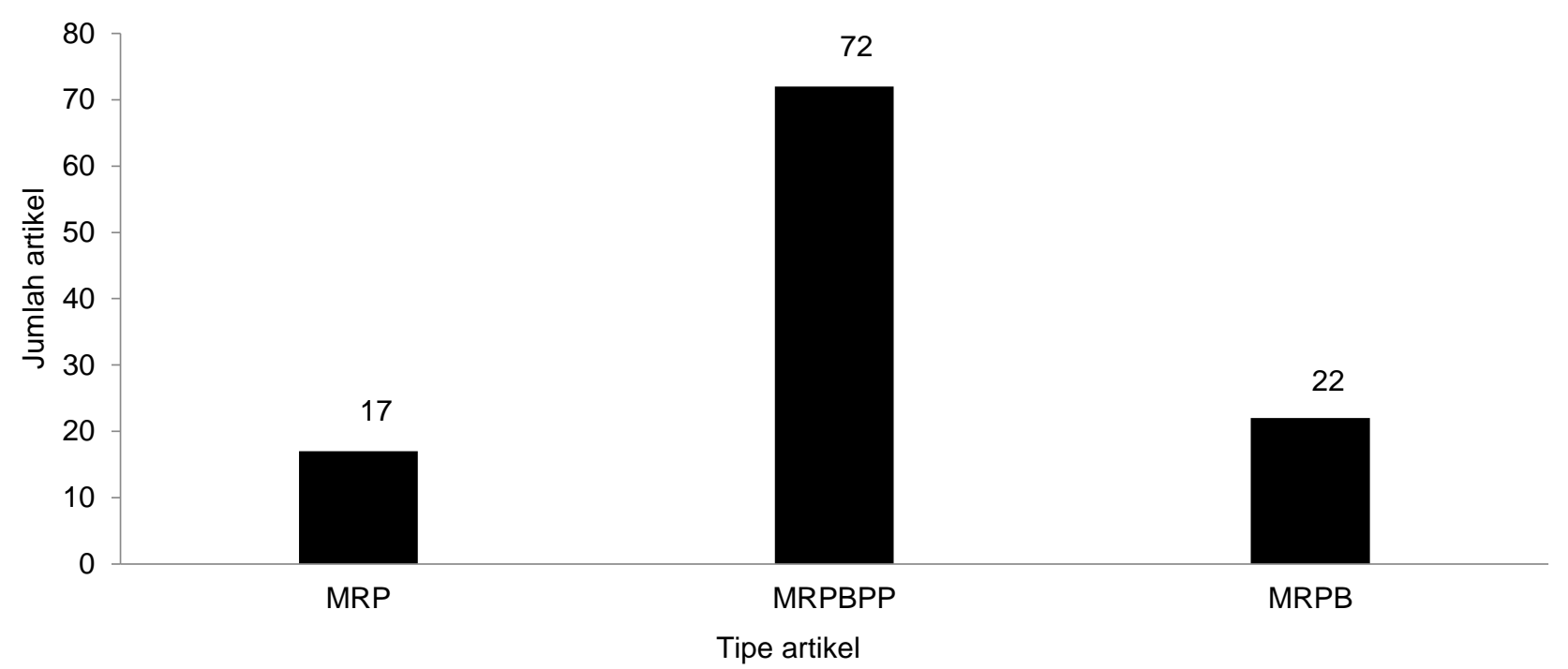

Gambar 1 Jumlah dan tipe artikel yang ditelaah. RP = Manajamen rantai pasok, RPBPP = Manajemen rantai pasok berkelanjutan produk pertanian, dan RPB = Manajemen rantai pasok berkelanjutan.

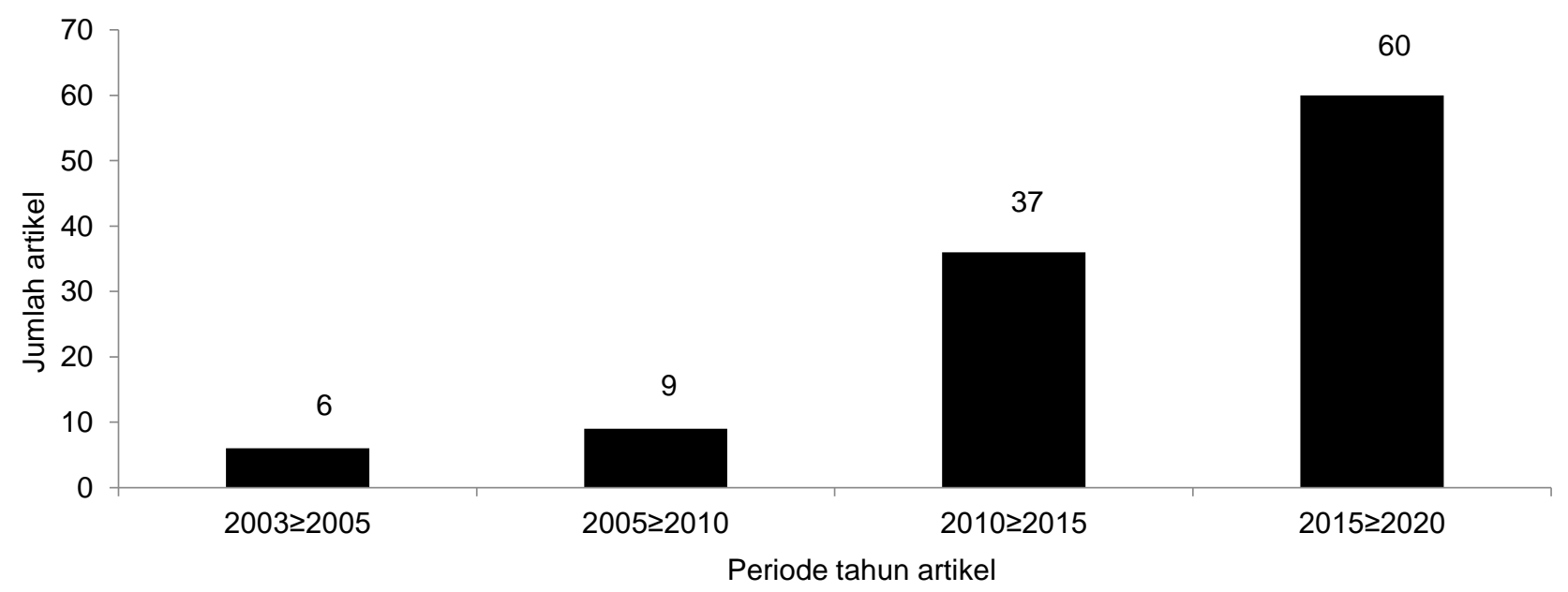

Gambar 2 Jumlah artikel yang ditelaah berdasarkan tahun terbit.

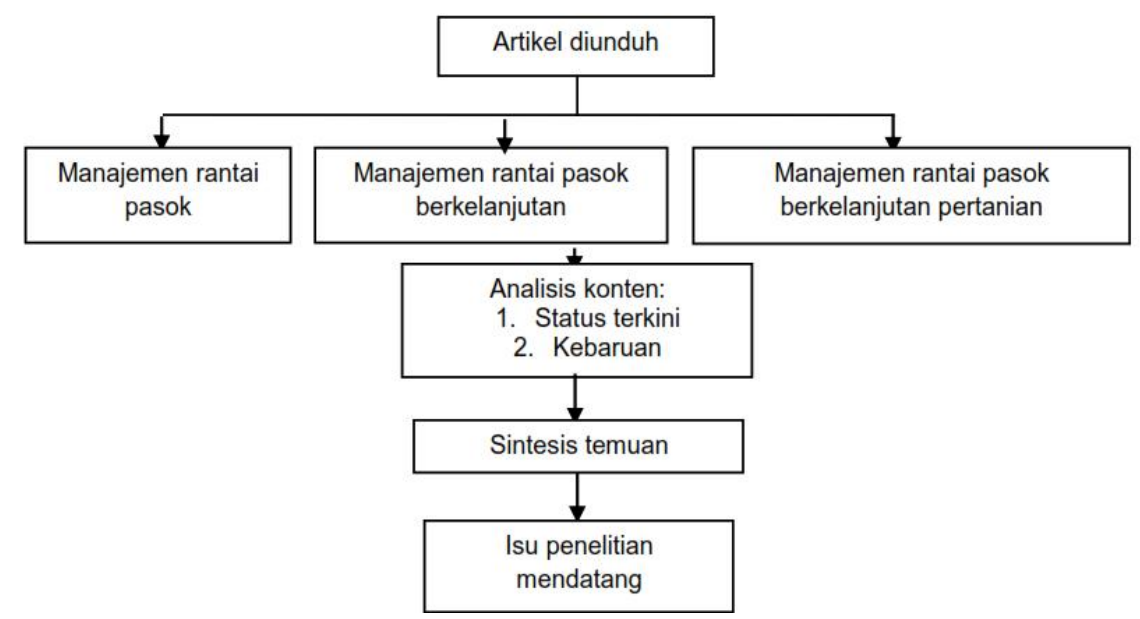

Gambar 3 Tahapan pelaksanaan kajian.

selanjutnya diserap oleh akademisi dan dunia usaha 
selanjutnya diserap oleh akademisi dan dunia usaha (Carter et al. 2015). Kata manajemen dalam sistem rantai pasok menunjukkan bahwa entitas yang terlibat tidak hanya satu/dua entitas bisnis, tetapi multientitas bisnis sehingga menjadi suatu sistem yang kompleks (Gunasekaran et al. 2014; Gunasekaran et al. 2015). Pada tataran teori, MRP masih dalam tahap pengembangan yang dapat dikaji dari sisi metodologi (Meixell \& Gargeya 2005; Simon et al. 2015).

Pada dasarnya, MRP adalah cara mengelola jejaring (network) dengan pokok bahasan mencakup aliran material, uang, dan informasi (van der Vorst 2004; Beamon 2008). Berdasarkan aspek teknis, MRP melibatkan lintas bidang keilmuan ke dalam satu sistem. Bidang keilmuan mencakup sistem produksi hulu-hilir (budi daya, pascapanen dan olahan, pengemasan, logistik, dan transportasi). Fakta menunjukkan bahwa MRP merupakan suatu sistem yang kompleks, pengelolaanya tentunya membutuhkan perangkat yang mampu mengelola kompleksitas tersebut secara efektif dan efisien (Kassmann \& Allgor, 2006; Gumus \& Guneri, 2009). Berkaitan dengan konteks kekinian, penggunaan instrumen berbasis industri 4.0, seperti bigdata, Internet of Thing (IOT), Block-chain, kecerdasan buatan, simulasi sangat relevan dalam pengelolaan MRP (Shen et al. 2018, Boiko et al. 2019; Mirabelli \& Solina 2020), termasuk juga penggunaan manajemen pengetahuan (Schniederjans et al. 2020).

\section{Manajemen Rantai Pasok Berkelanjutan}

Manajemen rantai pasok berkelanjutan (MRPB) merupakan pengembangan dari MRP, yang dalam konseptual dan operasionalnya terdapat interrelasi aspek ekonomi, sosial, dan lingkungan (Seuring \& Muller 2008; Gerrits 2020). Berdasarkan aspek histori, kata berkelanjutan (sustainable) bermakna kepedulian manusia terhadap kerusakan alam dan generasi mendatang (Mitham 1995; Klarin 2018) atau yang lebih dikenal dengan konsep Triple Bottom Line yang digagas oleh Elkington (Liu et al. 2017) pada tahun 2002 (Gambar 4). Konsep tersebut kemudian dijabarkan oleh World Commission on Environment and Development (WCED 1987) (Syahruddin 2013).

Pada konteks MRPB, adakalanya terminologi MRPB dihubungkan dengan Manajemen Rantai Pasok Hijau (MRPH) (green supply chain) yang pada dasarnya adalah operasionalisasi MRPB dengan memperhatikan aspek lingkungan dan sosial, tidak hanya sebatas kepentingan ekonomi (Gunasekaran et al. 2015; Silva et al. 2019). Selain itu, terdapat juga terminologi yang menggunakan permintaan (demand) sehingga akronimnya menjadi MRDB (Vural 2015) dengan klaim bahwa sistem yang dibangun lebih berorientasi pada konsumen dan pasar.

Pada tataran implementasi, Zimon et al. (2019) telah melakukan ekstrak pada komponen utama dalam sistem MRPB yang mencakup reaktif, kolaboratif, dan dinamis. Makna ketiga item tersebut adalah strategi yang dapat dilakukan oleh entitas bisnis, dalam melaksanakan sistem produksi pada kerangka MRPB. Berkaitan dengan aspek yang terdapat dalam MRPB, strategi reaktif berhubungan dengan ekonomi, kolaboratif dengan sosial dan lingkungan, sedangkan dinamis berkaitan dengan upaya entitas bisnis dalam pencapaian keunggulan kompetitif dengan mengaplikasikan ketiga item secara dinamis. Olga (2012) menyatakan bahwa pencapaian keberlanjutan dalam sistem MRP dapat dicapai melalui pengelolaan aliran material, pengelolaan hubungan (relationship), dan pengelolaan informasi melalui implementasi instrument berbasis industri 4.0 (Saetta \& Caldarelli 2020).

Pada saat kegiatan penelitian dengan topik MRPB sedang banyak dilaksanakan, terdapat penelitian yang berpendapat apakah makna keberlanjutan benarbenar dapat dicapai sistem produksi (bisnis) yang rumit? (Nieuwenhuis et al. 2019), bahkan telaah review Seuring \& Muller (2008) dari tahun 1994-2007, tidak satupun penelitian yang membahas aspek sosial dalam MRPB, kecuali Rota et al. (2013); Liu et al. (2017) yang sudah secara lengkap mengkaji ketiga aspek dalam satu sistem MRPB. Hal ini menunjukkan bahwa laju kerusakan lingkungan diduga memiliki bobot yang lebih besar, dibandingkan dengan aspek sosial dan lingkungan (Montabon et al. 2016).

Selain berhubungan dengan ketiga aspek yang menjadi konseptual berkelanjutan, perkembangan terkini juga telah mencakup aspek kelembagaan. Menurut Anantanyu (2011), peran kelembagaan menjadi sangat penting pada saat ini, terutama yang berkaitan dengan sektor pertanian. Dengan berkelompok, posisi tawar masing-masing pelaku yang terlibat dalam sistem rantai pasok akan lebih baik, terutama pelaku petani yang umumnya memiliki posisi tawar yang rendah dibandingkan dengan pelaku lain, seperti agroindustri maupun eksportir. Pada sisi yang lain, dalam sistem usaha justru risiko yang ditanggung petani lebih besar dibandingkan dengan yang ditanggung oleh eksportir, padahal keuntungan yang didapat eksportir umumnya jauh lebih besar dibandingkan dengan yang didapat oleh petani.

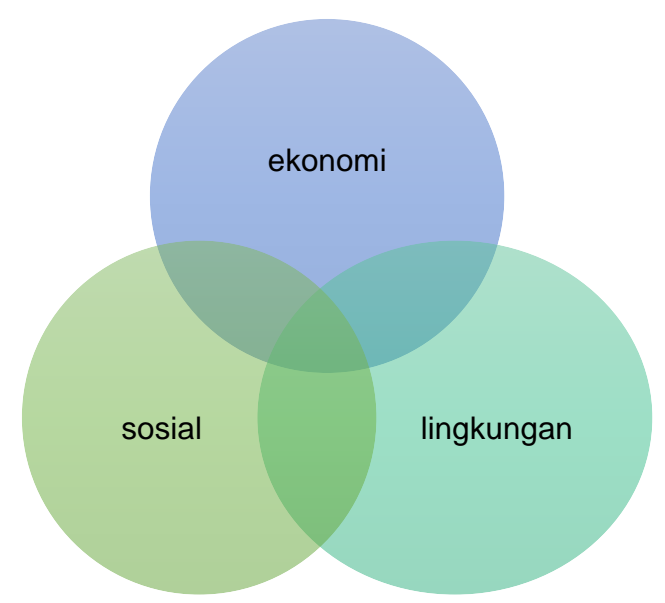

Gambar 4 Simplifikasi konsep sistem manajemen rantai pasok berkelanjutan (adaptasi Liu et al. 2017). 


\section{Manajemen Rantai Pasok Berkelanjutan Produk Pertanian}

\section{- Konsep dasar}

Dasar pengelolaan manajemen rantai pasok berkelanjutan produk pertanian (MRPBPP) adalah bahwa bahan dasar produk pertanian memiliki karakteristik yang berbeda dari produk nonpertanian, yaitu mudah rusak (perishable), kamba (bulky), musiman (seasonal), lokasi yang terpencar, serta mutu yang beragam (Wedowati et al. 2014). Fakta ini yang diusahakan diubah, yang pada negara-negara maju hal ini sudah mampu direkayasa, sebagai contoh komoditas jagung dan kedelai di Amerika Serikat dan Australia. Pada negara berkembang, seperti Indonesia, upaya ke arah tersebut sudah mulai dilakukan melalui inisiasi pengembangan pertanian berbasis sistem korporasi (Musthofa \& Kurnia 2018). Berdasarkan karakteristik tersebutlah pengelolaan MRPBPP dilakukan.

Dalam teori sistem rantai pasok pengelolaan material, informasi, dan uang dilakukan pada semua lini (tier) yang terlibat, dengan pola arah hulu-hilir atau hilir-hulu, waktu yang mandiri atau bersama-sama (gradual). Tujuan pengelolaan sistem manajemen rantai pasok adalah menjamin produk (jadi/setengah jadi) sampai ke konsumen berdasarkan tepat waktu (time-delivery), tepat mutu (responsiveness), dan tepat jumlah. Pada saat yang bersamaan, aktor yang terlibat juga menjamin sistem pembayaran (arus kas) sampai ke semua lini yang terlibat (Beamon 1998; Meixell \& Gargeya 2005; Marimin \& Magfiroh 2010). Sementara itu, aspek berkelanjutan mendeskripsikan bahwa implementasi sistem manajemen rantai pasok tersebut dilaksanakan berbasis interrelasi aspek ekonomi, sosial, dan lingkungan (Seuring \& Muller 2008).

Dalam tataran konseptual MRPBPP, sintesis beberapa terminologi di atas adalah penggelolaan manajemen rantai pasok produk pertanian secara berkelanjutan dengan pilar berupa karakteristik produk pertanian, dengan tujuan mengantarkan produk tersebut sampai ke konsumen.

\section{State of the Art MRPBPP}

Penelitian mengenai MRPBPP mulai dilakukan pada awal millennium dan sampai dengan saat ini masih terus dilakukan, tentunya dengan substansi yang lebih beragam dan mendalam (basis komoditas dan metode yang digunakan). Pada awal millennium, substansi kajian MRPBPP masih terbatas berbasis komoditas (produk pangan dan pertanian) yang dihubungkan dengan kerangka berkelanjutan (Seuring \& Muller 2008; Ahumada \& Villalobos 2009; Kumar \& Kushwaha 2014). Dengan instrument kajian yang diaplikasikan, umumnya pemodelan berbasis multicriteria decision making (MCDM), Life-cycle assessment (LCA), dan equilibrium model (Seuring, 2012).

Memasuki dasawarsa ke dua, penelitian MRPBPP telah berbasis komoditas, seperti kopi, kakao, katun, gula, pisang, susu, tembakau, sayuran, dan buah- buahan segar, kelapa sawit, teh, daging sapi, dan unggas (Tabel 1). Walaupun penelitian berbasis produk pangan masih tetap dilakukan, tetapi bebasis tier rantai pasok seperti retail dan distributor (PérezMesa et al. 2019), dengan pendalaman materi penelitian pada peningkatan efektivitas dan efisiensi sistem ratai pasok. Jika diteliti lebih mendalam produk pertanian yang dikaji merupakan produk pangan utama, yang melibatkan sistem perdagangan lintas negara. Instrumen yang digunakan mencakup aplikasi item-item pada industri 4.0 (Kamble et al. 2020).

Mendekati tahun 2020, topik-topik penelitian MRPBPP lebih bernuansa pada implementasi instrument 4.0, seperti big data, internet of thing, kecerdasan buatan dengan tujuan mengefisienkan sistem rantai pasok (to short tier), transparansi sistem informasi (produk dan harga). Hal ini dalam kaitanya dengan pilar berkelanjutan yang mencerminkan pengurangan emisi dari transportasi, keadilan terhadap keuntungan masing-masing tier, dan mereduksi potensi terjadinya kecurangan dalam sistem perdagangan (Gadner et al. 2019; Yang et al. 2019; Read et al. 2020; Yan et al. 2020).

\section{Temuan dan Isu Penting Penelitian Mendatang}

Salah satu aspek penting dalam suatu penelitian adalah adanya kebaharuan penelitian yang dilaksanakan. Konsep dasar penelitian MRPBPP adalah triple bottom line (TBL) yang membahas dimensi ekonomi (profit), lingkungan (planet), dan sosial (people). Dasar awal kerangka MRPBPP adalah irisan antara ketiga dimensi tersebut (Gambar 4) yang mengacu pada Liu et al. (2017). Dasar kajian ini adalah pentingnya untuk melihat perkembangan bidang keilmuan manajemen rantai pasok dalam satuan waktu (road-map) sehingga senjang kajian (riset-gap) dapat terlihat dengan jelas (Tabel 2).

Pada awalnya, bidang keilmuan sistem logistik, dan mulai diperkenalkan sebagai suatu bidang keilmuan oleh Oliver \& Webber pada awal tahun 80-an. Kemudian terus bertransformasi sesuai dengan dinamika yang terjadi (komoditas, metode, dan instrumen), termasuk juga di dalamnya transformasi konsep berkelanjutan dalam manajemen rantai pasok. Dalam kajian ini ditemukan pada Gambar 4 menjadi suatu sistem baru (Gambar 5).

Berdasarkan Gambar 5 terlihat bahwa hubungan antara masing-masing aspek keberlanjutan tidak lagi berdasarkan irisan dalam suatu sistem MRPBPP, akan tetapi dalam bentuk satu kesatuan. Hal ini menunjukkan bahwa tidak ada lagi ruang (irisan) pada masing-masing aspek, seperti Gambar 4. Pengertian ruang di sini menggambarkan aktivitas MRP yang tidak berkaitan dengan konsep berkelanjutan. Gambar 5 menunjukkan bahwa semua aktivitas dalam sistem MRPBPP seharusnya sudah mengakomodir makna berkelanjutan, dari sisi ekonomi, lingkungan, dan sosial dengan bobot kepentingan yang sama. Lapisan antarmasing-masing aspek tidak menunjukkan bobot yang lebih besar antarmasing-masing aspek. Dalam 
Tabel 1 Penelitian manajamen rantai pasok berkelanjutan produk pertanian berdasarkan substansi dan komoditas

\begin{tabular}{|c|c|c|c|}
\hline Judul/tahun/jurnal & Peneliti & Substansi & Komoditas/pro \\
\hline $\begin{array}{l}\text { Supply chain approach to sustainable beef } \\
\text { production from } \\
\text { perspective/2004/Livestock Prod. System }\end{array}$ & Filho & $\begin{array}{l}\text { Ekonomi, lingkungan, } \\
\text { sosial }\end{array}$ & Daging sapi \\
\hline $\begin{array}{l}\text { Integrating green supply chain into an } \\
\text { embryonic eco-industrial development: a case } \\
\text { study of the Guitang group/2004/J. of Cleaner } \\
\text { Production }\end{array}$ & Zhu and Cote & Lingkungan, ekonomi & Gula \\
\hline $\begin{array}{l}\text { Measuring the sustainability of the food supply } \\
\text { chain: a case study of the UK/2007/J. of Env. } \\
\text { Policy \& Planning }\end{array}$ & Yakovleva & $\begin{array}{l}\text { Ekonomi, lingkungan, } \\
\text { sosial }\end{array}$ & Produk pangan \\
\hline $\begin{array}{l}\text { Controlling sustainability in the cotton supply } \\
\text { chain/2011/University of Gothenburg }\end{array}$ & Lindskog \& Roth & $\begin{array}{l}\text { Lingkungan, ekonomi, } \\
\text { sosial }\end{array}$ & Katun \\
\hline $\begin{array}{l}\text { Sustainable production of raw and refined cane } \\
\text { sugar/2011/SIT Conference }\end{array}$ & Rein & $\begin{array}{l}\text { Lingkungan, ekonomi, } \\
\text { sosial }\end{array}$ & Gula rafinasi \\
\hline $\begin{array}{l}\text { Development of sustainable food supply } \\
\text { chain/2012/ Int. J. of Engineering and } \\
\text { Technology }\end{array}$ & Xiao-hui \& Jun & $\begin{array}{l}\text { Ekonomi, lingkungan, } \\
\text { sosial }\end{array}$ & Produk pangan \\
\hline $\begin{array}{l}\text { Sustainable management of coffee industry by- } \\
\text { product and value addition-review/2012/ } \\
\text { Resources, Concervation } \\
\text { Recycling }\end{array}$ & Muthy \& Naidu & Lingkungan, ekonomi & Kopi \\
\hline $\begin{array}{l}\text { Sustainable food supply chains: the role of } \\
\text { collaboration and sustainable relationships } \\
\text { (review)/2013/ Int. J. of Business and Social } \\
\text { Science }\end{array}$ & Rota et al. & $\begin{array}{l}\text { Ekonomi, lingkungan, } \\
\text { sosial }\end{array}$ & Produk pangan \\
\hline $\begin{array}{l}\text { Sustainable supply chain management in the } \\
\text { food sector: geographies of knowledge, power, } \\
\text { collaboration and } \\
\text { technology/2013/Dissertation }\end{array}$ & Cox & Sosial, lingkungan & Produk pangan \\
\hline $\begin{array}{l}\text { Sustainable supply chain management: a case } \\
\text { study of Indonesia's r cocoa } \\
\text { industry/2013/Bulletin of Indonesian Economic } \\
\text { Studies }\end{array}$ & Syahruddin & Ekonomi, sosial & Kakao \\
\hline $\begin{array}{l}\text { Sustainability analysis for Gayo coffee supply } \\
\text { chain/2013/Int. J. on Adv. Sci. Engineering Inf. } \\
\text { Tech. }\end{array}$ & Jaya et al. & $\begin{array}{l}\text { Ekonomi, lingkungan, } \\
\text { sosial }\end{array}$ & Kopi Gayo \\
\hline $\begin{array}{l}\text { Sustainable food supply chain } \\
\text { management/2014/ Int. J. of Production } \\
\text { Economics }\end{array}$ & Li et al. & Ekonomi, lingkungan & Produk pangan \\
\hline $\begin{array}{l}\text { Food supply chain management sustainability: } \\
\text { a review/2014/Res. j. of science and IT } \\
\text { management }\end{array}$ & Kumar \& Kushwaha & Ekonomi, lingkungan & Produk pangan \\
\hline $\begin{array}{l}\text { Supply chain management and sustainability in } \\
\text { agri-food system: Italian evidence/2014/J. of } \\
\text { Nutr. Ecology and Food Research }\end{array}$ & $\begin{array}{l}\text { Zecca } \\
\text { Rastorgueva }\end{array}$ & Sosial, ekonomi & Produk pangan \\
\hline $\begin{array}{l}\text { Integrated supply chain model for sustainable } \\
\text { poultry production in Bangladesh: a system } \\
\text { dynamics approach/2014/ Curtin University }\end{array}$ & Shamsuddoha & $\begin{array}{l}\text { Ekonomi, } \\
\text { lingkungan }\end{array}$ & Unggas \\
\hline $\begin{array}{l}\text { Best banana processing practices for } \\
\text { sustainable banana supply chain management: } \\
\text { Thailand perspective/2014/ Int. J. of } \\
\text { Management Sciences and Business } \\
\text { Research }\end{array}$ & Suvittawat & Ekonomi, sosial & Pisang \\
\hline $\begin{array}{l}\text { A supply chain approach to study efficiency and } \\
\text { sustainability in the Nepalese tea } \\
\text { industry/2014/Turku University }\end{array}$ & Shrestha & Ekonomi, sosial & Teh \\
\hline $\begin{array}{l}\text { Sustainability initiatives driving supply chain: } \\
\text { climate governance on beef production } \\
\text { System/2015/ J. Technol. Manag. Innov. }\end{array}$ & Makiya \& Fraisse & Lingkungan, ekonomi & Daging sapi \\
\hline $\begin{array}{l}\text { Sustainability issues in the sugar cane supply } \\
\text { chain/2015/SOMO }\end{array}$ & Kiezebrink et al. & Lingkungan, sosial & Gula \\
\hline $\begin{array}{l}\text { Sustainability assessment of food supply } \\
\text { chains: an application to local and global bread } \\
\text { in Italy/2015/ Agricultural and Food Economics }\end{array}$ & Galli et al. & $\begin{array}{l}\text { Ekonomi, lingkungan, } \\
\text { sosial }\end{array}$ & Roti \\
\hline
\end{tabular}

kondisi tertentu, bisa saja aspek keberlanjutan berada 
Tabel 1 Lanjutan

\begin{tabular}{|c|c|c|c|}
\hline Judul/tahun/jurnal & Peneliti & Substansi & Komoditas/produk \\
\hline $\begin{array}{l}\text { Developing sustainability in the Italian meat } \\
\text { supply chain: an empirical investigation/2016/ } \\
\text { Int. J. of Prod. Research }\end{array}$ & Golini et al. & $\begin{array}{l}\text { Ekonomi, lingkungan, } \\
\text { sosial }\end{array}$ & Daging sapi \\
\hline $\begin{array}{l}\text { Designing sustainable production and } \\
\text { distribution scenarios for the beef and pork } \\
\text { supply chains in Brazil/2016/ Int. J. Food } \\
\text { System Dynamics. }\end{array}$ & Dondè et al. & $\begin{array}{l}\text { Ekonomi, lingkungan, } \\
\text { sosial }\end{array}$ & Daging sapi \& babi \\
\hline $\begin{array}{l}\text { Sustainable supply chain network design: A } \\
\text { case of the wine industry in Australia/2016/ The } \\
\text { Int. J. of Manag. Science }\end{array}$ & $\begin{array}{l}\text { Varsei } \\
\text { Polyakovskiy }\end{array}$ & $\begin{array}{l}\text { Ekonomi, lingkungan, } \\
\text { sosial }\end{array}$ & Anggur (wine) \\
\hline $\begin{array}{l}\text { Sustainable wine supply chain and } \\
\text { entrepreneurship. The exploitation of by- } \\
\text { products in a waste management } \\
\text { process/2016/Int. J. of Business Science and } \\
\text { Applied Management }\end{array}$ & Malindretos et al. & $\begin{array}{l}\text { Ekonomi, lingkungan, } \\
\text { sosial }\end{array}$ & Anggur (wine) \\
\hline $\begin{array}{l}\text { Prioritization of green practices in GSCM: case } \\
\text { study with companies of the peach } \\
\text { industry/2016/Gest. Prod., São Carlos }\end{array}$ & Sellitto \& Hermann & Lingkungan, ekonomi & Peach \\
\hline $\begin{array}{l}\text { Is the short food supply chain an efficient } \\
\text { solution for sustainability in food market?/2016/ } \\
\text { Agriculture and Agricultural Science Procedia }\end{array}$ & Canfora & $\begin{array}{l}\text { Lingkungan, ekonomi, } \\
\text { sosial }\end{array}$ & Pangan \\
\hline $\begin{array}{l}\text { Environmental and social sustainability in the } \\
\text { fresh fruit and vegetables supply chain: a } \\
\text { competitiveness'asset/2016/Handbooks }\end{array}$ & Tecco et al. & Lingkungan, sosial & Buah segar \& sayuran \\
\hline $\begin{array}{l}\text { Agriculture and sustainability of the welfare: the } \\
\text { role of the short supply chain }\end{array}$ & Fazio & Sosial, ekonomi & Produk pertanian \\
\hline $\begin{array}{l}\text { Collaboration for Sustainability in the Food } \\
\text { Supply Chain: A Multi-Stage Study in } \\
\text { Italy/2017/Sustainability }\end{array}$ & León-Bravo et al. & Sosial, lingkungan & Produk pangan \\
\hline $\begin{array}{l}\text { Determinants of the acceptance of sustainable } \\
\text { production strategies among dairy farmers: } \\
\text { development and testing of a modified } \\
\text { technology acceptance model/2017/ } \\
\text { Sustainability }\end{array}$ & Naspetti et al. & Lingkungan, sosial & Dairy product \\
\hline $\begin{array}{l}\text { Blueberry supply chain in Italy: management, } \\
\text { innovation and } \\
\text { sustainability/2017/Sustainability }\end{array}$ & Peano et al. & $\begin{array}{l}\text { Lingkungan, sosial, } \\
\text { ekonomi }\end{array}$ & Blueberry \\
\hline $\begin{array}{l}\text { Sustainable supply chain performance } \\
\text { measurement a case study of the sugar } \\
\text { industry/2017/ Proc. of the Int. Conf. on Indust } \\
\text { Eng. and Operations Management }\end{array}$ & Sopadang et al. & $\begin{array}{l}\text { Ekonomi, lingkungan, } \\
\text { sosial }\end{array}$ & Gula \\
\hline $\begin{array}{l}\text { Green supply chain-solutions to improve the } \\
\text { competitiveness of Thainguyen tea/2017/The } \\
\text { Sixth Int. Conf. on Entrep. and Business } \\
\text { Management }\end{array}$ & Khuyen \& Yen & $\begin{array}{l}\text { Ekonomi, sosial, } \\
\text { lingkungan }\end{array}$ & Teh \\
\hline $\begin{array}{l}\text { Sustainable coffee supply chain management: } \\
\text { a case study in Buon Me Thuot City, Daklak, } \\
\text { Vietnam/2018/ Int. J. of Corporate Social } \\
\text { Responsibility }\end{array}$ & Nguyen \& Sarker & Sosial, lingkungan & Kopi \\
\hline $\begin{array}{l}\text { Menuju rantai pasok kelapa sawit yang lebih } \\
\text { berkelanjutan dan efisien di Berau, Kalimantan } \\
\text { Timur/2018/Climate Policy Initiative }\end{array}$ & Mafira et al. & $\begin{array}{l}\text { Ekonomi, lingkungan, } \\
\text { sosial }\end{array}$ & Kelapa sawit \\
\hline $\begin{array}{l}\text { Rantai pasok minyak kelapa sawit nestlé di } \\
\text { Indonesia/2018/The Danish Institute Human } \\
\text { Right \& The Forest Trust }\end{array}$ & Hoffmann \& Bansal & Sosial, ekonomi & Kelapa sawit \\
\hline $\begin{array}{l}\text { Issues of justice and sustainability in banana } \\
\text { trade in the light of Cameroon case } \\
\text { study/2018/Int. J. of Public and Private Persp. } \\
\text { on Healthcare, Culture, and the Env. }\end{array}$ & Ollong & $\begin{array}{l}\text { Sosial, lingkungan, } \\
\text { ekonomi }\end{array}$ & Pisang \\
\hline $\begin{array}{l}\text { Sustainable supply chain management } \\
\text { practices and sustainability performance in the } \\
\text { food industry/2018/ The South East Asian } \\
\text { Journal of Management }\end{array}$ & Emamisaleh et al. & $\begin{array}{l}\text { Ekonomi, lingkungan, } \\
\text { sosial }\end{array}$ & Produk pangan \\
\hline
\end{tabular}

kondisi tertentu, bisa saja aspek keberlanjutan berada 
Tabel 1 Lanjutan

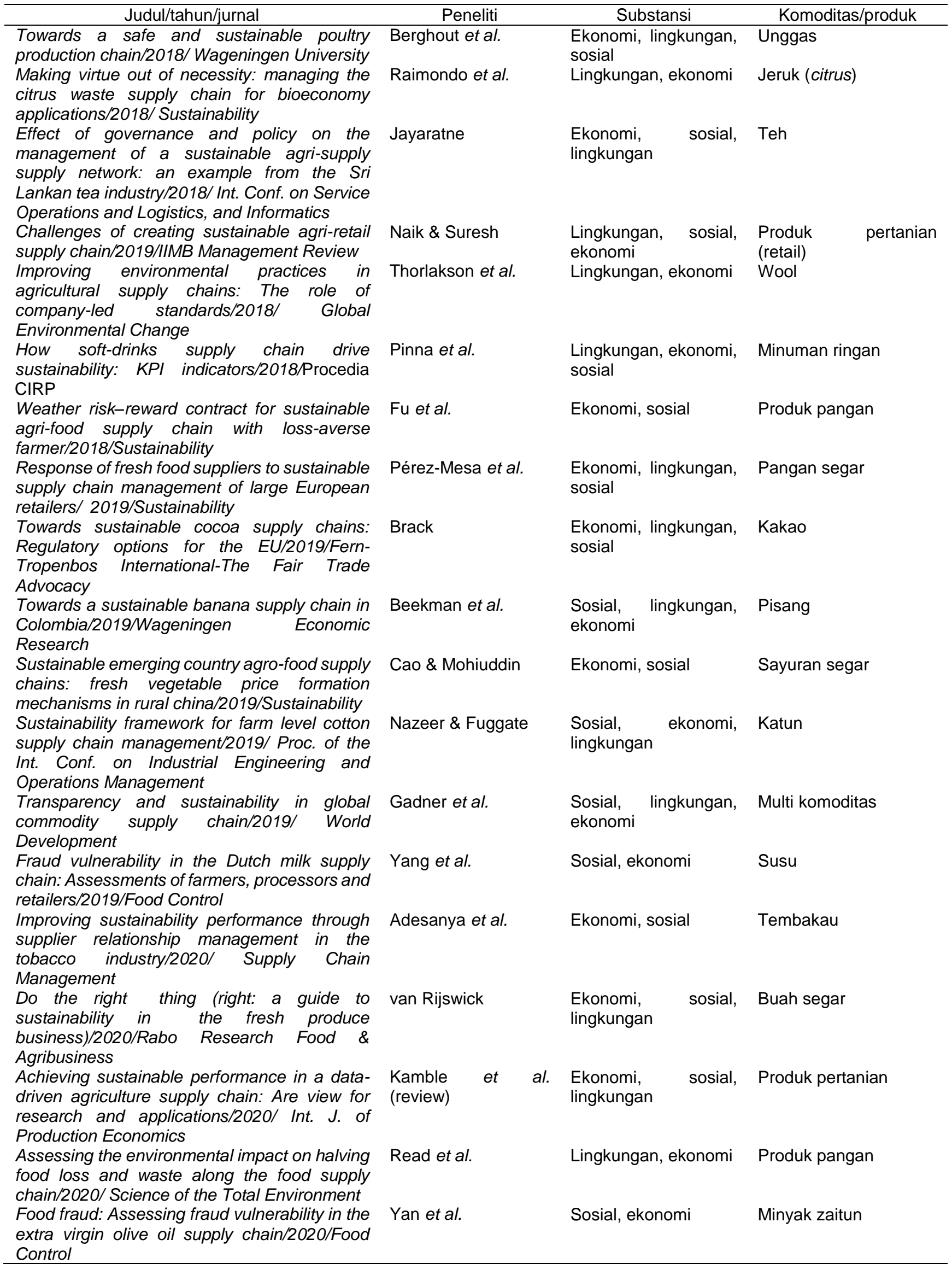

kondisi tertentu, bisa saja aspek keberlanjutan berada 
Tabel 2 Peta jalan (road-map) manajemen rantai pasok

\begin{tabular}{|c|c|c|c|}
\hline \multicolumn{4}{|c|}{ Substansi kajian/tahun } \\
\hline Awal tahun 80-an & Tahun 90-an & Tahun 2000-an & Tahun 2010-sekarang \\
\hline Manajemen logistik & \multicolumn{2}{|c|}{ Manajemen Rantai pasok } & Rantai pasok berkelanjutan \\
\hline $\begin{array}{l}\text { - } \text { Transportasi } \\
\text { - Penyimpanan } \\
\text { - Pergudangan } \\
\text { - Produksi } \\
\text { - } \text { Mutu produk } \\
\text { - } \text { Time-delivery }\end{array}$ & $\begin{array}{l}\text { - Transportasi } \\
\text { - Penyimpanan } \\
\text { - Pergudangan } \\
\text { - Produksi } \\
\text { - Mutu produk } \\
\text { - Time-delivery } \\
\text { - Traceability } \\
\text { - Kinerja } \\
\text { - Risiko }\end{array}$ & $\begin{array}{l}\text { - Transportasi } \\
\text { - Penyimpanan } \\
\text { - Pergudangan } \\
\text { - Produksi } \\
\text { - Mutu produk } \\
\text { - Time-delivery } \\
\text { - Traceability } \\
\text { - Kinerja } \\
\text { - Risiko } \\
\text { - Eco-labeling }\end{array}$ & $\begin{array}{ll}\text { - } & \text { Traceability } \\
\text { - } & \text { Kinerja } \\
\text { - } & \text { Implementasi konsep berkelanjutan } \\
& \text { (produksi ramah lingkungan) } \\
\text { - } & \text { Eco-labeling } \\
\text { - Kelembagaan } \\
\text { - } \text { Profit-sharing } \\
\text { - Risk-balancing }\end{array}$ \\
\hline \multicolumn{4}{|c|}{ Metode \& teknik } \\
\hline $\begin{array}{lll}\text { - } & \text { Statistik } & \text { kontrol } \\
& \text { proses } \\
\text { - } & \text { Optimasi tujuan } \\
& \text { tunggal } \\
\text { - } & \text { Manajemen mutu total } \\
\text { - } & \text { Penunjang keputusan }\end{array}$ & $\begin{array}{l}\text { - Statistik kontrol } \\
\text { proses } \\
\text { - Optimasi tujuan } \\
\text { jamak } \\
\text { - Agile manufacturing } \\
\text { - Lean production } \\
\text { - CRM } \\
\text { - Konsep produksi } \\
\text { bersih }\end{array}$ & $\begin{array}{ll}\text { - } & \text { Logika Fuzzy } \\
\text { - } & \text { Neural network } \\
\text { - } & \text { Algoritma } \\
& \text { genetika } \\
\text { - } & \text { Teknologi sensor } \\
\text { - } & \text { e-CRM } \\
\text { - } & \text { SCOR } \\
\text { - } & \text { NIR }\end{array}$ & $\begin{array}{ll}\text { - } & \text { Instrumen berbasis era industri } 4.0 \\
\text { - } & \text { Data mining } \\
\text { - } & \text { Big data } \\
\text { - } & \text { Internet of thing } \\
\text { - } & \text { Mechine-learning } \\
\text { - } & \text { Teknologi sensor } \\
\text { - } & \text { e-CRM } \\
\text { - Logika Fuzzy } \\
\text { - } & \text { Neural network } \\
\text { - } & \text { Algoritma genetika } \\
\text { - } & \text { Teknologi sensor } \\
\end{array}$ \\
\hline
\end{tabular}

Keterangan: $\mathrm{CRM}=$ Consumer relationship manajemen .

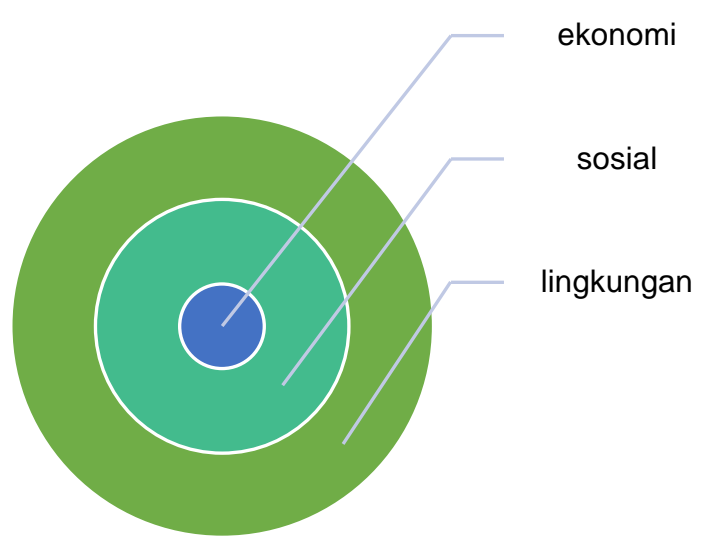

Gambar 6 Pola hubungan antara masing-masing aspek kerberlanjutan

kondisi tertentu, bisa saja aspek keberlanjutan berada pada lapisan yang berbeda. Selain ketiga aspek yang menjadi konseptual dalam sistem rantai pasok berkelanjutan, aspek kelembagaan juga menjadi salah satu titik kunci dalam pengelolaan rantai pasok berkelanjutan, terutama pada produk pertanian. Justifikasi dari hal ini adalah dengan menganut sistem berkelompok tentunya posisi tawar dari pelaku rantai pasok berkelanjutan produk pertanian akan semakin baik, terutama pada pelaku petani.

Secara umum topik-topik penelitian mendatang pada lingkup bidang keilmuan manajemen rantai pasok berbasis produk pertanian berkelanjutan dapat dipetakan setidaknya menjadi 3 subbidang keilmuan berbasis substansi komoditas pertanian dan metode yang digunakan. Pengembangan metode berhubungan erat dengan implementasi instrumen eraindustri 4.0, seperti big data, internet of thing, internet of people, serta beberapa teknik berbasis sistem cerdas, seperti logika fuzzy, jaringan saraf tiruan, dan algoritma genetika.

\section{KESIMPULAN}

Perkembangan bidang keilmuan MRP sangat pesat, pada saat ini fokus utama kajian MRP cenderung ke arah MRPB karena tuntutan global terhadap aspek berkelanjutan (ekonomi, sosial, lingkungan, dan kelembagaan), akan tetapi dengan sistem pengelolaan yang telah bertransformasi, yaitu bobot kepentingan ketiga aspek harus seimbang agar sistem bisnis tetap terjaga. Berdasarkan sektor pertanian (MRPBPP), kajian lebih condong ke komoditas perdagangan dunia. Pada sisi yang lain memasuki dasawarsa kedua milenial, untuk meningkatkan efektivitas, efisiensi, dan daya saing, umumnya penelitian MRPBPP lebih mengutamakan implementasi instrument-instrumen pada industri 4.0, seperti big data, block-chain, internet of thing, kecerdasan buatan, dan robotic. Selain bertumpu pada aspek ekonomi, sosial dan lingkungan, konseptual berkelanjutan juga telah mengadopsi aspek kelembagaan aspek selanjutnya yang patut dikaji 
sehingga senjang (gap) dalam bidang keilmuan manajemen rantai pasok dapat terpenuhi

\section{DAFTAR PUSTAKA}

Adams M, Ghaly AE. 2007. Maximizing sustainability of the Costarican coffee industry. Journal of Cleaner Production. 15: 1716-1729. http://doi:10.1016/ j.jclepro.2006.08.013

Adesanya A, Yang B, lqdara FB, Yang Y. 2020. Improving sustainability performance through supplier relationship management in the tobacco industry. Supply Chain Management. ahead-ofprint. http://doi:10.1108/scm-01-2018-0034

Ageron B, Gunasekaran A, Spalanzani A. 2011. Sustainable supply management: an empirical study. International Journal Production Economics. Article inpress. http://doi:10.1016/j.ijpe.2011.04.007

Ahumada O, Villalobos JR. 2009. Application of planning models in the Agri-food supply chain: A review. European Journal of Operational Research. 195: 1-20. http://doi:10.1016/j.ejor.2008.02.014

Al-odeh M, Smallwood J. 2012. Sustainable supply chain management: literature review, trends, and framework. International Journal of Computational Engineering \& Management. 15(1): 85-90.

Anantanyu S. 2011. Kelembagaan petani: peran dan strategi pengembangan kapasitasnya. Sepa. 7(2): 102-109.

Apaiah RK, Hendrix EMT. 2004. Design of a supply chain network for pea-based novel protein food. Journal of Food Engineering. 70(3): 383-391. http://doi.org/10.1016/j.jfoodeng.2004.02.043

Beekman G, Dekkers M, Koster T. 2019. Towards a sustainable banana supply chain in Colombia; Rainforest alliance certification and economic, social and environment conditions on small-scale banana plantations in Magdalena, Colombia. Wageningen Economic Research. [report]. https://doi.org/10.18174/466678

Boiko A, Shendryk V, Boiko O. 2019. Information system for supply chain management: uncertainties, risks and cyber security. Procedia Computer Science. 149: 65-70.

Beamon BM. 1998. Supply chain design and analysis: models and methods. International Journal of Production Economics. 55(3): 281-294.

Beamon BM. 2008. Sustainability and the future of supply chain management. Operations and Supply Chain Management. 1(1): 4-18.

Berghout J, Roland W, Vollebregt M, Koene M, de Jong I. 2018. Towards a safe and sustainable poultry production chain. Wageningen Livestock Research. [technical report]. https://doi.org/10.18174/461783

Canfora I. 2016. Is the short food supply chain an efficient solution for sustainability in food market? Agriculture and Agricultural Science Procedia. 8: 402-407. http://doi:10.1016/j.aaspro.2016.02.036

Carter CR, Rogers DS, Choi TY. 2015. Toward the theory of the supply chain. Journal of Supply Chain Management. 51(2): 25.

Cao Y, Mohiuddin M. 2019. Sustainable emerging country agro-food supply chains: fresh vegetable price formation mechanisms in rural China. Sustainability. 11(2814): 1-14. http://doi: 10.3390/su11102814

Chopra S. 2003. Designing the distribution network in a supply chain. Transportation Research Part E. 39: 123-140. PII: S1366-5545(02)00044-3.

Christopher M. 1998. Logistic and supply chain management: strategies for reducing cost and improving service. London: $2^{\text {nd }}$ Edition financial times and prentice hall.

Cox L. 2013. Sustainable supply chain management in the food sector: geographies of knowledge, power, collaboration and technology. University of of Nottingham [dissertation].

Cuthbertson R. 2011. The need for sustainable supply chain management di dalam sustainable supply chain management: practical ideas for moving towards best practice. Springer-Verlag Berlin Heidelberg.

Donde G, Trienekens J, Bloemhof JM. 2016. Designing sustainable production and distribution scenarios for the beef and pork supply chains in Brazil. Int. J. Food System Dynamics. 7(4): 271-292. http:// dx.doi.org/10.18461/ijfsd.v7i4.741

Emamisaleh K, Rahmani K, Iranzadeh S. 2018. Sustainable supply chain management practices and sustainability performance in the food industry. The South East Asian Journal of Management. 12(1): 1-19.

Fazio MD. 2016. Agriculture and sustainability of the welfare: the role of the short supply chain. Agriculture and Agricultural Science Procedia. 8: 461-466. http://doi:10.1016/j.aaspro.2016.02.044

Filho KE. 2004. Supply chain approach to sustainable Beef production from Brazil perspective. Livestock Production System. 90: 53-61. http://doi: 10.1016/j.livprodsci.2004.07.006

Fritz MCM. 2019. Sustainable supply chain management. Di dalam Responsible Consumption and Production, W. Leal Filho et al. (eds.). Springer Nature Switzerland AG.

Fu H, Teo KL, Li Y, Wang L. 2018. Weather risk-reward contract for sustainable agri-food supply chain with 
loss-averse farmer. Sustainability. 10(4540): 1-25. http://doi:10.3390/su10124540

Galli F, Bertolini F, Brunori G, Colombo L, Gava O, Grando S, Marescotti M. 2015. Sustainability assessment of food supply chains: an application to local and global bread in Italy. Agricultural and Food Economics. 3: 1-17. http://dx.doi.org/10.1186/ s40100-015-0039-0

Gardner TA, Benzie M, Borner J, Dawkins E, Fick S, Garrett R, Godar J, Grimard A, Lake S, Larsen RK, Mardas N, McDermott CL, Meyfroidt P, Osbeck M, Persson M, Sembers T, Suavet C, Strassburg B, Trevisan A, West C, Wolvekamp P. 2019. Transparency and sustainability in global commodity supply chain. World Development. 121: 161-177. https://doi.org/10.1016/j.worlddev.2018. 05.025

Gerrits R. 2020. Sustainability in the supply chain: guidance note on tolls for pollution management for growth and competitiveness. Worldbank [internet]. [diunduh 2020 April 2]. www.Worldbank.org.

Golini R, Moretto A, Caniato F, Caridi M, Kalchschmidt M. 2016. Developing sustainability in the Italian meat supply chain: an empirical investigation. International Journal of Production Research. 55(4): 1183-1209. http://dx.doi.org/10.1080/00207543. 2016.1234724

Gunasekaran A, Hong F, Fujimoto T. 2014. Building supply chain system capabilities in the age of global complexity: Emerging theories and practices. International Journal Production Economics. 147: 189-197. http://doi.org/10.1016/j.ijpe.2013.11.012

Gunasekaran A, Subramanian N, Rahman S. 2015. Supply chain resilience: role of complexities and strategies. International Journal of Production Research. 53(22): 6809-6819. http://doi: 10.1080/00207543.2015.1093667

Gunasekaran A, Subramanian N, Rahman S. 2015. Green supply chain collaboration and incentives: Current trends and future directions. Transportation Research Part E. 74: 1-10. http://dx.doi.org/10.1016/j.tre.2015.01.002

Gumus AT, Guneri AF. 2009. A multi-echelon inventory management framework for stochastic and fuzzy supply chain. Journal Expert System with Application, 36: 5565-5575. http://doi:10.1016/ j.eswa.2008.06.082

Golicic SL, Smith CD. 2013. A meta-analysis of environmentally sustainable supply chain management practices and firm performance. Journal of Supply Chain Management. 49(2): 7895.

Hoffmann D, Bansal T. 2018. Rantai pasok minyak kelapa sawit nestlé di Indonesia. The Danish
Institute for Human Rights \& The Forest Trust. [working papper]. Copenhagen.

Hsieh HF, Shannon SE. 2005. Three approaches to qualitative content analysis. Qualitative Health Research. 15(9): 1277-1288.http://doi:10.1177/ 1049732305276687

Jaya R, Machfud, Raharja S, Marimin. 2013. Sustainability analysis for Gayo coffee supply chain. International Journal Advanced Science Engineering Information Technology. 3(2): 24-28.

Jayaratne P. 2018. Effect of governance and policy on the management of a sustainable agri-supply supply network: an example from the Sri Lankan tea industry. Intnational Conference Service Operationsand Logistics, and Informatics (SOLI). Singapura (SG), 31 July-2 August.

Kassmann D, Allgor R. 2006. Supply chain design, management and optimization. 16th European Symposium on Computer Aided Process Engineering and and 9th International Symposium on Process Systems Engineering. Marquardt \& Pantelides (Editors). Elsevier B.V.

Khuyen PTM, Yen PTM. 2017. Green supply chain solutions to improve the competitiveness of Thainguyen tea. The Sixth Int. Conf. on Entrepreneurship and Business Management. Hanoi (VN), 16-17 November.

Kiezebrink V, van der Wal S, Theuws M. 2015. Sustainability issues in the sugar cane supply chain.Stichting Onderzoek Multinationale Ondernemingen (SOMO). Amsterdam (NL). www.somo.nl

Klarin T. 2018. The concept of sustainable development: from its beginning to the contemporary issues. Zagreb International Review of Economics \& Business. 21(1): 69-74.

Kumar A, Kushwaha GS. 2014. Food Supply chain Management sustainability: A Review. Research Journal of Science and IT Management. 3(10): 3042.

Leon-bravo V, Caniato F, Caridi M, Johnsen T. 2017. Collaboration for sustainability in the food supply chain: a multi-stage study in Italy. Sustainability. 9(1253): 1-21.http://doi:10.3390/su9071253

Li D, Wang X, Manzini R. 2014. Sustainable food supply chain management. International Journal Production Economics. 152: 1-6. http://dx.doi.org/10.1016/j.jpe.2014.04.003

Lindskog L, Roth M. 2011. Controlling sustainability in the cotton supply chain. University of Gothenburg. [thesis] Bachelor of Science in Economics.

Liu W, Bai E, Liu L, Wei W. 2017. A framework of sustainable service supply chain management: a literature review and research agenda. 
Sustainability. 9(421): 1-25. http://doi:10.3390/ su9030421

Lu D. 2011. Fundamentals of supply chain management. Ventus publishing ApS.

Mafira T, Rakhmadi R, Novianti C. 2018. Menuju rantai pasok kelapa sawit yang lebih berkelanjutan dan efisien di Berau, Kalimantan Timur. [internet] [diunduh tanggal 27 Pebruari 2020]. Tersedia pada: www.climatepolicyinitiative.org

Makiya IK, Fraisse CW. 2015. Sustainability initiatives driving supply chain: climate governance on beef production system. Journal Technology Management and Innovation. 10(1): 215-224. http://www.jotmi.org

Malindretos G, Tsiboukas K, Argyropoulou-Konstantaki S. 2016. Sustainable wine supply chain and entrepreneurship. The exploitation of by-products in a waste management process. International Journal of Business Science and Applied Management. 11(2): 34-46.

Marimin, Magfiroh N. 2010. Aplikasi teknik pengambilan keputusan dalam manajemen rantai pasok. Bogor (ID): IPB-Press.

Meixell MJ, Gargeya VB. 2005. Global supply chain design: A literature review and critique. Transportation Research Part E, 41: 531-550. http://doi:10.1016/j.tre.2005.06.003

Mirabelli G, Solina V. 2020. Blockchain and agricultural supply chains traceability: research trends and future challenges. Procedia Manufacturing. 42: 414-421.

Mitcham C. 1995. The concepts of sustainable development: its origin and ambivalence. Technology in Society. 17(3): 311-326.

Montabon FL, Pagell M, Wu Z. 2016. "Making Sustainability Sustainable,". Journal of Supply Chain Management. 52(2): 11-27.

Murthy PS, Naidu MM. 2012. Sustainable management of coffee industry by-product and value additionreview. Resources,Concervation,Recycling. 66: 45-58. http://dx.doi.org/10.1016/j.resconrec.2012. 06.005

Musthofa I, Kurnia G. 2018. Prospek penerapan sistem corporate farming. AGRISEP. 16 (1): 11-22. http://doi10.31186/jagrisep.17.1.11-2

Naik G, Suresh DN. 2018. Challenges of creating sustainable agri-retail supply chain. IIMB Management Review. 30: 270-282. https:// doi.org/10.1016/j.iimb.2018.04.001

Nguyen GNT, Sarker T. 2018. Sustainable coffee supply chain management: a case study in Buon Me Thuot City, Daklak, Vietnam. International Journal of Corporate Social Responsibility. 3(1): 1-17. http://doi 10.1186/s40991-017-0024-x.
Naspetti S, Mandolesi S, Buysse J, Latvala T, Nicholas P, Padel S, van Loo EJ, Zanoli R. 2017. Determinants of the acceptance of sustainable production strategies among dairy farmers: development and testing of a modified technology acceptance model. Sustainability. 9(1805): 1-16. http://doi:10.3390/su9101805

Nazeer S, Fuggate P. 2019. Sustainability framework for farm level cotton supply chain management. Proceedings of the International Conference on Industrial Engineering and Operations Management. Bangkok (TH), March 5-7.

Nieuwenhuis P, Touboulic A, Matthews L. 2019. Is Sustainable Supply Chain Management Sustainable? di dalam Sustainable Development Goals and Sustainable Supply Chains in the Post-global Economy, Yakovleva et al. [eds] SpringerLink.

Olga C. 2012. Sustainable supply chain management: theoretical literature overview. International Institute for Industrial Environmental Economics, [working paper] Lund University [SE].

Ollong KAA. 2018. Issues of justice and sustainability in banana trade in the Light of Cameroon case study. International Jornal of Public and Private Perspectives on Healthcare, Culture, and the Environment. 2(1): 1-19. http://doi:10.4018/ijppphce.2018010101

Peano C, Girgenti V, Baudino C, Giuggioli NR. 2017. Blueberry supply chain in Italy: management, innovation and sustainability. Sustainability. 9(261): 1-17. http://doi:10.3390/su9020261

Pérez-Mesa JC, Piedra-Muñoz L, García-Barranco MA, Giagnocavo C. 2019. Response of Fresh Food Suppliers to Sustainable Supply Chain Management of Large European Retailers. Sustainability. 11(3885): 1-24. http://doi: 10.3390/su11143885

Pinna C, Demartini M, Tonelli F, Terzi S. 2018. How soft-drinks supply chain drive sustainability: KPI indicators. Procedia CIRP. 72: 862-867.

Raimondo M, Caracciolo F, Cembalo L, Chinnici G, Pecorino B, D'Amico M. 2018. Making virtue out of necessity: managing the citrus waste supply chain for bioeconomy applications. Sustainability. 10(4821): 1-19. http://doi: 10.3390/su10124821

Read QD, Brown S, Cuellar AD, Finn SM, Gaphart JA, Marston LT, Meyer E, Muth MK. 2020. Assessing the environmental impact on halving food loss and waste along the food supply chain. Science of the Total Environment. 712(136255): 1-11. http://doi.org/10.1016/j.scitotenv.2019.136255 
Rein PW. 2011. Sustainable production of raw and refined cane sugar. Paper presented to SIT Conference. Montreal, Canada.

Rota C, Reynolds N, Zanasi C. 2013. Sustainable food supply chains: the role of collaboration and sustainable relationships. International Journal of Business and Social Science. 4(4): 45-53.

Saeed MA, Kersten W. 2019. Drivers of sustainable supply chain management: identification and classification. Sustainability. 11(1137): 1-23. http://doi:10.3390/su11041137

Saetta S, Caldarelli V. 2020. How to increase the sustainability of the agri-food supply chain through innovation in 4.0 perspective: a first case study analysis. Procedia Manufacturing. 42: 333-336.

Schniederjans DG, Curado C, Khalajhedayati M. 2020. Supply chain digitization trends: An integration of knowledge management. International Journal of Production Economics. 220(107439): 1-11. http://doi.org/10.1016/j.ijpe.2019.07.012

Sellitto MA, Hermann FF. 2016. Prioritization of green practices in GSCM: case study with companies of the peach industry. Gest. Prod., São Carlos. 23(4): 871-886. $530 \times 2516-15$

Seuring S, Muller M. 2008. From a literature review to a conceptual framework for sustainable supply chain management. Journal of Cleaner Production. 16: 1699-1710. http://doi:10.1016/j.jclepro. 2008.04.020

Seuring S. 2012. A Review of modeling approaches for sustainable supply chain management. Decision support systems. 54(4): 1513-1520. http:// doi:10.1016/j.dss.2012.05.053

Shamsuddoha M. 2014. Integrated supply chain model for sustainable poultry production in Bangladesh: a system dynamics approach. [thesis] Doctor of Philosophy. Perth [AU]: Curtin University.

Shen Q, Zhang J, Hou YX, Yu JH, Hu JY. 2018. Quality control of the agricultural product supply chain based on internet. Information Processing in Agriculture. 5: 394-400.

Shrestha B. 2014. A supply chain approach to study efficiency and sustainability in the Nepalese tea industry. [thesis] Bachelor, Turku University.

Silva WH, Guarnieri P, Carvalho JM, Farias JS, dos Reis SA. 2019. Sustainable supply chain management: analyzing the past to determine a research agenda. Sustainability. 3(14): 1-15. http://doi:10.3390/logistics3020014

Simon AT, di Serio LC, Pires SRI, Martins GS. 2015. Evaluating supply chain management: a methodology based on a theoretical model. 19(1):
26-44. http://doi.org/10.1590/1982-7849rac2015 1169

Sopadang A, Wichaisri S, Banomyong R. 2017. Sustainable supply chain performance measurement a case study of the sugar industry. Proceedings of the International Conference on Industrial Engineering and Operations Management. Rabat (MA), April 11-13.

Suvittawat D. 2014. Best banana processing practices for sustainable banana supply chain management: Thailand perspective. International Journal of Management Sciences and Business Research. 3(12): 1-6.

Syahruddin N. 2013. Sustainable supply chain management: a case study of Indonesia's cocoa industry. Bulletin of Indonesian Economic Studies. 49(1): 114-115. http://dx.doi.org/10.1080/0007 4918.2013.779770

Tebaldi L, Bigliardi, B, Bottani E. 2018. Sustainable supply chain and innovation: A review of the recent literature. Sustainability. 10(3946): 1-29.http:// doi:10.3390/su10113946.

Tecco N, Giuggioli N, Girgenti V, Peano C. 2016. Environmental and social sustainability in the fresh fruit and vegetables supply chain: a competitiveness' asset. Di dalam Sustainable Supply Chain Management. Krmac E. [eds]. IntechOpen. http://dx.doi.org/10.5772/63377

Thomas DJ, Griffin PM. 1996. Coordinated supply chain management [invited review]. European Journal of Operation Research. 95: 1-15

Thorlakson T, Hainmueller J, Lambin EF. 2018. Improving environmental practices in agricultural supply chains: The role of company-led standards. Global Environmental Change. 48: 32-42. https://doi.org/10.1016/j.gloenvcha.2017.10.006.

van Rijswick C. 2020. Do the right thing (right); a guide to sustainability in the fresh produce business. Rabo Research Food \& Agribusiness.Berlin [internet].[diunduh tanggal 20 Pebruari 2020]. Tersedia pada: https://www.fruitlogistica.com/.

Vermeulen WJV, Kok MTJ. 2012. Government interventions in sustainable supply chain governance: Experience in Dutch front-running cases. Ecological Economics, article in press. http://doi:10.1016/j.ecolecon.2012.04.006.

Vorst JGAJ van der. 2004. Supply chain management: Theory and practice. Di dalam: Camps, T., Diederen P., Hofstede GJ., Vosb. The Emerging World of Chain and Networks. Hoofdstuk:Elsevier.

Vural CA. 2015. Sustainable demand chain management: an alternative perspective for sustainability in the supply chain. Procedia-Social 
and Behavioral Sciences. 207: 262-273. http:// doi:10.1016/j.sbspro.2015.10.095.

Wedowati ER, Singgih ML, Gunarta IK. 2014. Production system in food industry: a literature study. $6^{\text {th }}$ Int. Conf. on Operations and Supply Chain Management. Bali, Indonesia, December 10-12.

Xio-Hui Y, Jun M. 2012. Development of sustainable food supply chain. International Journal of Engineering and Technology. 4(2): 166-169.

Yakovleva N. 2007. Measuring the sustainability of the food supply chain: a case study of the UK. Journal of Environmental Policy \& Planning. 9(1): 75-100. http://doi:10.1080=15239080701255005

Yang $Y$, Huisman $W$, Hettinga KA, Liu N, Heck J, Schrijver GH, Gaiardoni L, van Ruth SM. 2019. Fraud vulnerability in the Dutch milk supply chain: Assessments of farmers, processors and retailers. Food Control. 95: 208-317. https://doi.org/ 10.1016/j.foodcont.2018.08.019
Yan J, Erasmus SW, Toro MA, Huang H, van Ruth SM. 2020. Food fraud: Assessing fraud vulnerability in the extra virgin olive oil supply chain. Food Control. 111(107801): 1-10. https://doi.org/10.1016/ j.foodcont.2019.107081

Zecca F, Rastorgueva N. 2014. Supply chain management and sustainability in agri-food system: Italian evidence. Journal of Nutritional Ecology and Food Research. 2: 20-28. http://doi: 10.1166/jnef.2014.1057

Zhu Q, Cote RP. 2004. Integrating green supply chain into an embryonic eco-industrial development: a case study of the Guitang group. Journal of Cleaner Production. 12: 1025-1035. http://doi:10.1016/ j.jclepro.2004.02.030

Zimon D, Tyan J, Sroufe R. 2019. Implementing Sustainable Supply Chain Management: Reactive, Cooperative, and Dynamic Models. Sustainability. 11(7227): 1-22. http://doi:10.3390/su11247227 